\title{
TESES AD FEUERBACH E A EDUCAÇÃo
}

\author{
Rafael Rossi $i^{1}$
}

Resumo: O presente texto aborda as Teses ad Feuerbach elaboradas por Marx, com intuito de extrair elementos de ordem ontometodológica que possam subsidiar a reflexão à filosofia da educação. Entendemos, na esteira de Lukács e Mészáros, que o pensamento marxiano se distingue qualitativamente do padrão de cientificidade moderno, em razão da instauração de uma ontologia de base materialista e dialética do ser social. Isso significa que a teoria social marxiana possui, como seu núcleo mais essencial, a historicidade na abordagem ontológica dos fenômenos sociais, buscando compreendê-los em sua gênese e na função social que desempenham no processo de reprodução social. Com isso, no texto aqui em debate, tratamos da radicalidade revolucionária do escrito abordado, em suas potencialidades ao debate educacional.

Palavras-Chave: Ontologia marxiana. Educação. Crítica.

O pensamento marxiano foi deturpado por uma série de interpretaçóes das mais variadas estirpes. Desde E. Bernstein, com seu "revisionismo", passando por L. Althusser; J. Stalin e tantos outros, que abdicaram da perspectiva eminentemente histórica e da radicalidade revolucionária intrínseca à nova teoria social elaborada por Marx. Ao que sabemos, foi apenas com G. Lukács, em sua monumental Para uma ontologia do ser social, que se descobriu a impostação ontológica presente nos escritos marxianos. Para ele, Marx, "vê com clareza que há toda uma série de determinaçóes categoriais, sem as quais nenhum ser pode ter seu caráter ontológico concretamente apreendido" (LUKÁCS, 2012 a, p. 27). Ou seja, ao contrário do que muitos "marxistas" fizeram com a teoria social de Marx, uma característica básica de

\footnotetext{
${ }^{1}$ Docente vinculado à Faculdade de Educação, ao Programa de Pós-Graduação em Educação e ao Programa de Pós-Graduação em Ensino de Ciências, na Universidade Federal de Mato Grosso do Sul (UFMS), Campo Grande, MS - Brasil. (D) https://orcid.org/0000-0001-8544-3756 E-mail: rafaelrossied@gmail.com
}

Licenciado e Mestre em Geografia pela Unesp/FCT de Presidente Prudente, SP. Doutor em Educação pela UFMS.

http://dx.doi.org/10.1590/0101-3173.2019.v42n2.05.p85

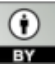

This is an open-access article distributed under the terms of the Creative Commons Attribution License. 
sua constituição mais íntima é a apreensão da realidade social enquanto uma "série de determinaçóes categoriais", isto é, a apreensão da realidade enquanto uma totalidade. Não é por um acaso qualquer que Lukács tenha escrito, em outro momento, que "a totalidade é o território da dialética" (LUKÁCS, 1974, p. 48). Dessa forma, excluímos logo no princípio toda e qualquer tentativa de imputar a Marx um reducionismo economicista ou uma simplificação rasa dos fenômenos sociais.

Contudo, não se trata de uma totalidade social desarticulada. A ontologia marxiana compreende a interaçáo entre os distintos complexos que compóem o ser social em íntima determinação recíproca e em sua dependência ontológica para com o trabalho, o que quer dizer que todos os complexos sociais (arte, filosofia, ciência, educação, geografia etc.) só podem existir no ser social em decorrência de os homens efetivarem atos de trabalho. Por isso mesmo, cada complexo possui uma função social distinta no processo de reprodução social, agindo no interior de um campo de possibilidades reais e concretas, matrizado pelo trabalho e pela totalidade e, com isso, a autonomia de cada um deles é sempre relativa e nunca absoluta. ${ }^{2}$

Além disso, há toda uma plêiade de discussões que seriam necessárias adentrar, para expor, mesmo que em linhas gerais, a historicidade e a radicalidade revolucionária presente na obra marxiana. Não é esse nosso objetivo. $\mathrm{O}$ intuito, com o presente texto, é destacar pontos para o debate, ou seja, apresentar hipóteses para discussão no âmbito da reflexão educacional. Compreendemos que, já em 1845, Marx apresentava sinais e tematizaçóes a respeito da realidade objetiva que permitem apreender, in status nascendi, uma nova concepção de mundo. Em outras palavras, já era possível constatar o surgimento da teoria social que, posteriormente, viria a se denominar por ontologia marxiana.

Desse modo, trazemos para a reflexão as famosas Teses ad Feuerbach, escritas por Marx em meados de 1845, em Bruxelas, e que foram publicadas pela primeira vez em 1888, por Engels, com o título "Marx sobre Feuerbach". Com efeito, nosso objetivo é introduzir uma reflexão que aponte para os princípios, já nascentes, da ontologia marxiana nessas teses de Marx, criticando Feuerbach, e que, por sua vez, possibilite pensar o complexo social da educação em interação com a totalidade social matrizada pelo trabalho em seu sentido ontológico, isto é, os traços gerais da ontologia marxiana presente

2 Para um contato mais profundo sobre essa discussão, recomendamos a leitura de Lukács (2012), Lessa (2012) e Tonet (2005). 
no texto supracitado permitem refletir sobre a educaçáo, tanto no sentido de não supervalorizá-la quanto para não subestimá-la. Portanto, neste texto, não trataremos sobre qual a polêmica que ocorreu entre Feuerbach e Marx, pois o que nos interessa explicitar são as determinaçóes mais essenciais da postura ontológica marxiana espelhada nas Teses e suas possibilidades para reflexão no campo educacional. Com efeito, entendemos que as Teses de Marx contra Feuerbach são importantes para reflexão da arquitetura mais geral da teoria social instaurada pelo revolucionário alemão e, dessa forma, apresentam importantes elementos para o debate educacional.

\section{AD FEUERBACH E A ONTOLOGIA}

Vamos analisar cada tese elaborada por Marx, para apreendermos seus traços mais gerais e suas possíveis contribuiçôes para a problemática da educação:

O principal defeito de todo o materialismo existente até agora (o de Feuerbach incluído) é que o objeto [Gegenstand], a realidade, o sensível, só é apreendido sob a forma do objeto [Objekt] ou da contemplação, mas não como atividade humana sensível, como prática; não subjetivamente. Daí o lado ativo, em oposição ao materialismo, [ter sido] abstratamente desenvolvido pelo idealismo - que, naturalmente, náo conhece a atividade real, sensível, como tal. Feuerbach quer objetos sensíveis [sinnliche Objekte], efetivamente diferenciados dos objetos do pensamento: mas ele não apreende a própria atividade humana como atividade objetiva [gegenstandlihe Tatigkeit], razão pela qual ele enxerga, na essência do cristianismo, apenas o comportamento teórico como o autenticamente humano, enquanto a prática é apreendida e fixada apenas em sua forma de manifestação judaica, suja. Ele não entende, por isso, o significado da atividade "revolucionária", "prático-crítica". (MARX, 2007, p. 533).

Nesta primeira tese de Marx, temos aspectos fundamentais de sua análise e de sua teoria social. Ele já havia elaborado sua crítica à filosofia de Hegel e, agora, também estava criticando Feuerbach enquanto um filósofo materialista. Todavia, e isso é preciso frisar, não se trata de uma crítica por descrédito ou com "ares academicistas". Ao contrário, a crítica marxiana significa a análise "lógica do processo real", porém, não uma lógica pensada especulativamente, mas sim uma lógica que emana do próprio processo histórico do movimento inerente à própria realidade. É a análise do processo real, com vistas a "apre- 
ender a sua natureza própria, suas contradiçốes, sua tendência, seus aspectos positivos e negativos, suas possibilidades e limites", levando sempre em conta "os lineamentos mais gerais e essenciais do processo social como um processo de autoconstrução humana" (TONET, 2005, p. 54).

Uma vez que compreendemos o que é crítica, em Marx, podemos, agora, avançar para a apreensão dos aspectos decisivos de sua primeira tese. Para o velho materialismo, a subjetividade pouco importa. Já para o idealismo clássico, é a ideia (ou o "espírito absoluto") o sujeito da história. A ontologia marxiana irá constatar o correto equacionamento entre objetividade e subjetividade, não como parâmetro de "equilíbrio homogêneo". Ao contrário: Marx nos sinaliza que, entre a subjetividade e a objetividade, há uma prioridade ontológica, ou seja, essencial e ineliminável, da objetividade. Isso não quer dizer que a subjetividade pouco possui de relevância, entretanto, que ela encontra seu campo de possibilidades de atuação delimitado e determinado pela própria realidade objetiva. Como ele pode afirmar isso? Justamente por constatar a história humana não como mera coleção de fatos aleatórios, contudo, construída a partir da "atividade humana sensível", isto é, construída como "prática".

Quando Marx assevera que Feuerbach quer "objetos sensíveis” que sejam "efetivamente diferenciados dos objetos do pensamento", ele está nos sinalizando que o velho materialismo não apreende a realidade social enquanto constructo da "prática" dos homens. No entanto, não se trata de uma prática "praticista", isto é, de uma "prática" isenta de subjetividade. A "atividade humana sensível" ou, em outros termos, o trabalho (em seu sentido ontológico: presente em todas as formaçóes sociais; com a função social de transformar a natureza para a produção dos valores de uso), articula, numa síntese dialética, objetividade e subjetividade. Para efetivar um ato de trabalho, é fundamental que se conheçam a realidade objetiva e as possibilidades que ela oferece, para que a prévia-ideação cumpra efetivamente com o fim teleologicamente traçado. Um exemplo do que estamos falando: para construir uma lança, a fim de abater um determinado animal, os homens primitivos tinham que construí-la com a madeira que a própria realidade objetiva oferecia, ou seja, não é possível construir uma lança com mogno, se essa não é uma possibilidade real e concreta.

Esse exemplo nos permite apreender como, para Marx, há um equacionamento novo na relação entre consciência e realidade social. Esta última precisa, para surgir e se desenvolver, do papel ativo da consciência. Todavia, isso não significa que seja o pensamento, por si só, o demiurgo do real. Há que se 
apreenderem os entraves e as potencialidades existentes na própria realidade e, por isso mesmo, trata-se da atividade sensivel humana, que elabora idealmente o fim a ser alcançado e, também, que objetiva, efetivamente, a construção do mundo social.

Pode-se constatar que, para a ontologia marxiana, não há um desprezo da subjetividade nem da objetividade, pois esta última coloca o campo real de possibilidades concretas sobre o qual a primeira tem de escolher e atuar. É em decorrência disso, também, que Marx irá afirmar que as categorias expressam "formas de ser", "determinaçóes da existência" (MARX, 2011, p. 85), pois a teoria deve traduzir idealmente o movimento do processo social real. Essa reflexão é fundamental para diferenciar a prática "suja ${ }^{3 "}$ e a "prática crítica", pois a primeira isola em dimensóes incomunicáveis a realidade social e o pensamento, enquanto a segunda, a partir da "atividade humana sensível", aborda os dois polos em íntima conexão com a prioridade ontológica, à qual já aludimos, da realidade social. A prática continua sendo prática e a teoria continua sendo teoria, porém, elas se articulam, elas se encontram efetivamente entrelaçadas com a prioridade da primeira no sentido já exposto.

A forma "prático-crítica" é "eminentemente humana porque o homem transfigura o real", ou seja, "o trabalho efetivo do homem é uma atividade transformadora", por exemplo: "transformar uma árvore numa mesa é operar uma revolução" (CHASIN, 1988, p. 57). Esta é uma "liçãoo" de fundamental importância no debate educacional. Muitas teses querem e defendem uma "educação crítica, transformadora, emancipadora, justa, igualitária, omnilateral" etc. e mais: muitas dessas teses acreditam e postulam que é possível uma educação com todos esses adjetivos, se cada educador, cada escola, cada "agente da educação" interiorizar esses valores, portanto, "conscientizar-se" e, assim, pouco a pouco se estaria mudando todo o complexo da educação ${ }^{4}$. Não conseguem apreender que a educação, assim como os demais complexos, é fundada pelo trabalho e que, na sua orientação geral, é a forma típica do trabalho naquela sociedade e a totalidade social que exercem a função de momento predominante (TONET, 2005). Portanto, a educação nunca foi e nem pode ser o principal complexo da transformação social. Ela pode contribuir com esse processo, no entanto, se não superarmos o trabalho assalariado, o capital,

\footnotetext{
${ }^{3}$ De modo geral, a "prática suja" não apreende o papel ativo da consciência na construção da vida social e, por isso mesmo, não reflete sobre a articulação da objetividade e da subjetividade. Tende-se, com isso, ou a uma supervalorização da consciência ou a um desprezo assintomático.

4 Para um aprofundamento dessa crítica, é decisiva a leitura de Tonet (2014) e Maceno (2016).
} 
o Estado, as classes sociais e toda forma de exploração do homem pelo homem, jamais conseguiremos uma educação - em seu conjunto - com todos aqueles atributos que tão comumente estão presentes nos mais variados discursos e teses. Em função disso está a importância em compreendermos que "é necessário romper com a lógica do capital se quisermos contemplar a criação de uma alternativa educacional significativamente diferente" (MÉSZÁROS, 2005, p. 27).

O que é possível realizar, ainda no capitalismo, é a defesa humano-genérica do processo educativo que preze pela transmissão e apropriação dos clássicos das ciências, das artes e da filosofia, numa orientação crítica ontológica, ou seja, preocupada com os interesses essenciais humano-genéricos (SAVIANI, 2011; DUARTE, 2016).

É preciso explicar um pouco mais a afirmação do parágrafo anterior: não estamos sustentando que a educaçáo náo possa influenciar, positivamente, rumo à uma transformação social humanamente referenciada. Entretanto, também não concordamos que seja possível o desenvolvimento de uma educação radicalmente diferente, ainda no interior da atual ordem social. Para que a educaçáo - enquanto dimensáo e complexo social como um todo - possa se modificar substancialmente e que, dessa maneira, possa atender às reais necessidades formativas humanas, é imprescindível que o sistema do capital seja superado, em sua totalidade. Isso significa algum imobilismo ou pessimismo, de alguma forma? Entendemos que não, já que, na sociedade capitalista, é possível o desenvolvimento e a promoção - mesmo que de forma restrita - de algumas atividades que conectem os indivíduos com o horizonte maior de construção de uma sociabilidade marcada pela emancipação humana, ou seja, marcada por uma sociedade sem qualquer tipo de exploração no processo de trabalho. Para isso, de modo bem geral, é imprescindível a apreensão dos clássicos da história e da filosofia, por exemplo, junto ao estudo do modo de funcionamento do sistema do capital e da teoria social marxiana (SAVIANI, 20111; DUATE, 2016).

Em resumo, esta primeira tese é decisiva para entendermos que "espírito e matéria, consciência e realidade, subjetividade e objetividade são dois momentos que constituem uma unidade indissolúvel” e, com isso, é a práxis que é a atividade "mediadora que faz com que da determinação recíproca destes dois momentos se origine toda a realidade social", portanto, "o defeito do materialismo está sanado quando a objetividade é captada como objetividade social" e "o defeito do idealismo está superado quando a realidade é capturada como o resultado da 'atividade real, sensível'." (TONET, 2005, p. 32). 
A segunda tese, por sua vez, argumenta:

II

A questão de saber se ao pensamento humano cabe alguma verdade objetiva [gegenstandliche Wahrheit] não é uma questão da teoria, mas uma questão prática. É na prática que o homem tem de provar a verdade, isto é, a realidade e o poder, a natureza interior [Diesseitigkeit] de seu pensamento. A disputa acerca da realidade ou náo realidade do pensamento - que é isolado da prática - é uma questão puramente escolástica. (MARX, 2007, p. 533).

Aqui, novamente, temos indícios fundamentais da relação entre teoria e prática. Para Marx, "o conhecimento teórico é o conhecimento do objeto - de sua estrutura e dinâmica - tal como ele é em si mesmo, na sua existência real e efetiva, independentemente dos desejos, das aspiraçóes e das representaçóes do pesquisador" (PAULO NETTO, 2011, p. 20, grifo nosso). A teoria é, dessa maneira, a "reprodução ideal do movimento real do objeto pelo sujeito que pesquisa: pela teoria, o sujeito reproduz em seu pensamento a estrutura e a dinâmica do objeto que pesquisa", e essa reprodução "será tanto mais correta e verdadeira quanto mais fiel o sujeito for ao objeto" (PAULO NETTO, 2011, p. 21).

Aqui está, claramente, o aspecto ontológico da teoria social instaurada por Marx. Todas as querelas e polêmicas conceituais/especulativas que perdem ou abandonam o lastro com a realidade são, por isso mesmo, uma questáo “puramente escolástica”, isto é, uma questão sem vínculo com o real. Marx não é um espontaneísta que só pensa na ação imediata e irresponsável. Ele não defendia a vinculaçáo dos trabalhadores em aventuras juvenis. $\mathrm{O}$ conhecimento teórico é indispensável para a compreensão do mundo, porém, não uma compreensão que se contente em contemplar. Isso ficará mais explícito na última tese. O que a ontologia marxiana entende é que, na prática, o pensamento ou, se quiserem, a teoria, mostra sua terrenalidade, sua mundaneidade. O conhecimento de construção de uma lança, por exemplo, se mostra verdadeiro quanto de fato construímos a lança e a utilizamos em uma determinada situação. Mesmo que ela quebre ou não atinja o fim pretendido, o "conhecimento teórico" deve captar a própria realidade para reelaboração do modo como trabalhar para construir a lança.

Também aqui há contribuiçôes para o debate em educação. Muitas teorias nos apresentam uma escola, um aluno, etc. que efetivamente não existem. 
Não existem, porque não podem existir modelos "abstratos" para a realidade social. Não é o conceito, ou a teoria, que determina a realidade, mas justamente o contrário, como o próprio Marx expóe, em outros momentos. Muitos pesquisadores educacionais se digladiam ao redor de disputas conceituais: qual conceito é mais revelador, qual "metodologia" está na moda, qual técnica de coleta de dados é a melhor, enfim, uma série de disputas que pensam as categorias por si mesmas, não entendendo o conhecimento teórico enquanto tradução intelectiva de fenômenos efetivamente reais. Marx chama a atenção, nesta segunda tese, para o fato de que "o pensamento é importante quando ele se põe como poder na exterioridade", pois um pensamento "que só fica no universo do pensamento é uma debilidade” (CHASIN, 1988, p. 58). A perspectiva ontológica instaurada pelo pensamento marxiano, de forma geral, coloca que "o saber depende do ser, pois é o saber de um dado ser e como o ser do homem é o ser de sua atividade, o seu saber é o saber de seu ser ativo", razão pela qual "o saber do ponto de vista da querela gnosiológica é o pensamento fora de suas condiçốes sensíveis de existência” (CHASIN, 1988, p. 59).

Novamente estamos diante de uma interpretação importante: transformar o mundo social, num sentido humanamente positivo, é romper com a lógica do capital. Os "educadores" precisam ser educados, o que, em nossa compreensão, indica a necessidade de os trabalhadores, de modo geral, terem acesso às formas mais desenvolvidas do conhecimento teórico, científico, histórico e filosófico, junto à teoria social marxiana, como elemento indispensável para compreender como o capital e o capitalismo funcionam e poderem desempenhar lutas no sentido da emancipação humana. Trata-se, dessa maneira, de uma prática de autoformatação extremamente necessária e, ao mesmo tempo, também de contribuição dos intelectuais quanto às reais demandas da classe trabalhadora, auxiliando a compreender a realidade social como ela é em sua essência e não apenas na sua camada mais fenomênica.

Vejamos a terceira tese:

III

A doutrina materialista sobre a modificação das circunstâncias e da educação esquece que as circunstâncias são modificadas pelos homens e que o próprio educador tem de ser educado. Ela tem, por isso, de dividir a sociedade em duas partes - a primeira das quais está colocada acima da sociedade. 
A coincidência entre a alteração das circunstâncias e a atividade ou automodificação humanas só pode ser apreendida e racionalmente entendida como prática revolucionária. (MARX, 2007, p. 533-534).

Essa tese é polêmica e emblemática, pois a expressão de "que o próprio educador deve ser educado", como assinala Chasin (1988), faz as "delícias de toda a pedagogia". Todavia, temos a reafirmação de pontos centrais do debate que estamos propondo: o papel ativo do homem em seu processo de autoconstrução humana, e não alguma potência mística ou transcendental, e a "prática revolucionária" inerente ao processo de constituição e complexificação do ser social, por meio da "atividade sensível humana". Quando Marx diz que as circunstâncias são modificadas pelos homens, ele não está caindo numa perspectiva idealista de que tudo podemos e que bastaria nos conscientizarmos. Como ele mesmo afirma, em seu $O 18$ de Brumário de Luís Bonaparte: "Os homens fazem a sua própria história; contudo, não a fazem de livre e espontânea vontade", pois "não são eles quem escolhem as circunstâncias sob as quais ela é feita, mas estas lhes foram transmitidas assim como se encontram" e, em face disso, "a tradição de todas as geraçóes passadas é como um pesadelo que comprime o cérebro dos vivos.” (MARX, 2011b, p. 25).

Ora, o que isso significa? Isso indica que os homens constroem a sua própria história, que a reprodução social é crescentemente um processo de socialização humana dos homens e de criação do novo; entretanto, cada geraçáo atua em meio às circunstâncias herdadas da geração passada e, alterando essas mesmas circunstâncias, elas deixarão um novo campo de possibilidades com que a geração futura irá atuar. Vejam que estamos diante de uma colocação genial, ao ponderar sobre o papel atuante dos homens, o qual, ao mesmo tempo, não é supervalorizado na regência absoluta da mera vontade, do mero desejo. Como toda análise realizada por Marx, também aqui temos explicitamente sua perspectiva histórica profundamente enraizada. Examinemos um exemplo: a burguesia, no processo de destruição do Estado absolutista e dos entraves que o feudalismo impunha ao desenvolvimento do capital e do trabalho assalariado, operou uma verdadeira revoluçáo, ao apresentar seu interesse particular como interesse geral e, com isso, chamou ao processo revolucionário outras classes e fragmentos de classe que posteriormente se tornaram inimigas da burguesia. Isso permite constatar o papel ativo dos homens na construçáo da própria história, que, contudo, não se dá de maneira homogênea e absolutamente previsível. 
Quando Marx critica a doutrina materialista a respeito da modificação das circunstâncias, ele novamente reafirma a tese de que o poder material tem de ser derrubado pelo poder material e de que a teoria também se torna força material, quando é apoderada pelas massas, como discutido já em 1843, em sua Crítica à filosofia do direito de Hegel. $\mathrm{O}$ fato de que os educadores também precisem ser educados elucida o papel prático-crítico da teoria, pois ela náo deve servir à mera contemplação, conforme já argumentamos, mas enquanto um conhecimento correto - ainda que nunca absoluto - da própria realidade social, com intuito de revolucioná-la. A discussão sobre teoria e prática aparece aqui, novamente, com todo seu potencial crítico para a discussão em educação. Os educadores precisam se educar em decorrência de uma série de fatores, e um deles, de fundamental relevância, concerne à necessidade histórica de compreensão essencial da lógica dessa forma de sociabilidade para superá-la, para erradicá-la e não para se colocar "acima da sociedade". Justamente por isso, a relaçáo e a articulaçáo, numa síntese indissolúvel entre teoria e prática, passa pela constatação de que a "alteração das circunstâncias", juntamente com a "atividade ou automodificação humanas", só pode "ser apreendida e racionalmente entendida como prática revolucionária”, segundo Marx nos explica, ao final da terceira tese.

Afirmar a necessidade de um conhecimento de caráter revolucionário e de um conhecimento correto indica-nos dois pontos fundamentais: 1) a necessidade de estudo e apreensão da natureza e da arquitetura mais geral da crítica presente na teoria social marxiana; e 2) o interesse dos trabalhadores, na luta pela construçáo de uma sociedade para além do capital, pelos conhecimentos que ensejem compreender a realidade como ela se estrutura essencialmente. $\mathrm{O}$ parâmetro para sabermos se um conhecimento é falso ou verdadeiro está na própria objetividade. É preciso confrontar as teses educacionais, por exemplo, com o conjunto do processo histórico real e verificar em que medida a educação está sendo articulada ou não com a respectiva totalidade social em que atua. Este deve ser o nosso critério para a delimitação de um conhecimento falso ou verdadeiro e não critérios relativistas. Por exemplo: sabemos que o ser humano não nasce ser humano, mas se forma enquanto tal. Em que medida e com quais estímulos e obstáculos é realmente algo a ser pesquisado. Contudo, se alguma pesquisa tentar provar que a maldade é inata ao ser humano, estaremos diante de um conhecimento falso, o qual náo corresponde ao que de fato se passa no ser social. 
É imprescindível, portanto, o estudo, a apropriação e a transmissão dos clássicos dos conhecimentos eruditos e clássicos, que avancem sobre as aparências do real (SAVIANI, 2011; DUARTE, 2016).

É impossível transmitir todo o conhecimento sistematizado e elaborado histórica e socialmente pela humanidade, sob a égide do sistema do capital. Muitos pesquisadores na área educacional não admitem isso, porém, é decisivo compreender que o capital impossibilita que essa transmissão se dê de modo universal, perante todos os trabalhadores. Assim, entendemos que esta terceira tese também permite refletir sobre a necessidade de um conhecimento de caráter revolucionário, que tenha por orientação a superação dessa forma de sociabilidade rumo à emancipação humana. Esse tipo de conhecimento deve ajudar a "compreender o conjunto do processo histórico de tal modo que ela a classe trabalhadora - se veja como sujeito capaz de transformar radicalmente o mundo" e, portanto, se trata de "um conhecimento que esteja, pela sua própria configuração, intimamente articulado com a transformação radical do mundo." (TONET, 2014, p. 06). Já a quarta crítica à Feuerbach postula:

\section{IV}

Feuerbach parte do fato da autoalienação [Selbstentfremdung] religiosa, da duplicação do mundo [Welt] num mundo religioso e num mundo mundano [weltliche]. Seu trabalho consiste em dissolver o mundo religioso em seu fundamento mundano. Mas que o fundamento mundano se destaque de si mesmo e construa para si um reino autônomo nas nuvens pode ser esclarecido apenas a partir do autoesclarecimento e do contradizera-si-mesmo desse fundamento mundano. Ele mesmo, portanto, tem de ser tanto compreendido em sua contradição quanto revolucionado na prática. Assim, por exemplo, depois que a terrena família é revelada como o mistério da sagrada família, é a primeira que tem, então, de ser teórica e praticamente eliminada. (MARX, 2007, p. 534).

Nesta tese, Marx relaciona, novamente, a interação entre objetividade e subjetividade. $\mathrm{Na}$ "atividade sensível humana", esses dois polos formam uma síntese indissolúvel, ainda que cada qual continue sendo uma dimensão própria. Já vimos como, para a ontologia marxiana, é a realidade objetiva que possui a prioridade ontológica desse processo, o que quer dizer que é a objetividade que coloca o campo de limites e possibilidades para a atuação dos demais complexos sociais. Nesse sentido, podemos lembrar que "a exigência de que abandonem as ilusóes acerca de uma condição é a exigência de que abandonem uma condição que necessita de ilusóes" (MARX, 2010, p. 146). Aqui 
temos explicitamente a regência da síntese analisada no polo da objetividade. Não basta criticar as ilusões. Isso é necessário, porém, insuficiente. Acabar com as ilusôes, alienaçôes etc. só é possível, se acabarmos com toda a realidade social objetiva que faz com que surjam essas mesmas ilusôes, alienaçóes etc. Marx não está desprezando o papel da crítica. Pelo contrário, ele está dando uma profundidade eminentemente radical à crítica que está efetuando, pois defende a completa revolução de uma determinada ordem social, para que suas ilusóes possam, enfim, ser extirpadas. Em razáo disso, "a crítica da religiấo desengana o homem a fim de que ele pense, aja, configure a sua realidade como um homem desenganado, que chegou à razão, a fim de que ele gire em torno de si mesmo, em torno de seu verdadeiro sol” (MARX, 2010 p. 146).

Apesar de náo ser o foco de nosso artigo, algumas consideraçôes a mais são imprescindíveis: romper com o capital e construir uma sociabilidade de emancipação humana significa, dentre inúmeros aspectos, acabar in totum com qualquer tipo de exploração, no processo de trabalho, já que aqui reside o germe das classes sociais, do capital e do Estado. Desse modo, uma sociedade que apresente possibilidades reais e concretas de os seres humanos se desenvolverem plenamente, em todas as suas dimensōes, é algo impossível enquanto vigorar o controle do capital. O sistema do capital é justamente a relação social que se origina a partir do processo de exploração do trabalho e se personifica, na contemporaneidade, nas multinacionais, banqueiros, grandes latifundiários, grandes conglomerados econômicos etc., os quais devem a sua riqueza à exploração do trabalho alheio de milhares de trabalhadores. Mészáros (2002) aborda essa questão, ao mostrar que as tentativas revolucionárias do passado não conseguiram romper justamente com o sistema do capital e, dessa maneira, não efetivaram o trânsito ao socialismo.

$\mathrm{Na}$ área educacional, foco deste escrito, muitas vezes esbarramos com teses que defendem a necessidade de criarmos uma escola que favoreça o desenvolvimento "omnilateral" dos seres humanos. Todavia, não se compreende que essa meta é inalcançável, no âmbito do capitalismo, ou seja, sem rompermos com o capital em todas as suas formas e manifestaçôes. Apenas numa sociedade onde o trabalho seja emancipado é possível que os indivíduos possam se desenvolver plenamente, enquanto seres humanos. Porém, essa é uma constatação de ordem ontológico-reflexiva, com base nas possibilidades inerentes ao próprio processo real. Isso se articula à crítica marxiana a Feuerbach, por exemplo, ao ponderar: 
Feuerbach, não satisfeito com o pensamento abstrato, quer a contemplação [Anschauung]; mas ele não compreende o sensível [die Sinnlichkeit] como atividade prática, humano-sensível. (MARX, 2007, p. 534).

Nesta quinta tese, temos a reafirmação dos pontos centrais por nós já discutidos anteriormente. Marx enfatiza que o velho materialismo, inclusive com Feuerbach, cancela a subjetividade, por não ter apreendido a "atividade prática, humano-sensível”. Desse modo, o pensamento marxiano pode avançar sobre as lacunas do idealismo e do materialismo, por partir da análise dos próprios homens, em seu processo social. Por isso, afirma que "o primeiro ato histórico é, pois, a produção dos meios para satisfação dessas necessidades, a produção da própria vida material", e esse ato histórico é, por seu turno, "uma condição fundamental de toda a história” (MARX; ENGELS, 2007, p. 33). E qual é a atividade prática que possibilita isso? $\mathrm{O}$ trabalho, enquanto única categoria fundante do ser social com a função de produzir a "própria vida material", ou seja, "os meios para satisfação dessas necessidades". Não é por um motivo qualquer que Lukács tenha afirmado que "o trabalho pode ser considerado o fenômeno originário, o modelo do ser social" e que deve ser analisado "adequadamente no interior e a partir da constituição global do nível de ser de que se trata” (LUKÁCS, 2012b, p. 41-44).

O trabalho funda o ser social e todas as demais dimensóes humanas, incluindo a educação. A interação, ou seja, o sistema de relaçốes entre todos os complexos sociais, formará a totalidade social. A educação terá a função social de transmitir os conhecimentos, habilidades, ideologias e valores que atendam às demandas de uma determinada totalidade construída historicamente. Marx "provou" teoricamente a possibilidade de os seres humanos construírem outra ordem social, sem a exploração do homem pelo homem. No caso da transição do capitalismo rumo à emancipação humana, temos a necessidade de esse processo ser efetivado pela classe trabalhadora, sob a liderança dos trabalhadores que efetivamente transformam a natureza com o seu trabalho: os proletários. Isso não quer dizer que apenas o proletariado deve participar, mas que, sem a sua participação, não há chances de construção da sociedade humanamente emancipada, já que são eles que estão no capitalismo, produzindo todo o conteúdo material da existência social, conforme Marx demonstra, em sua magnum opus. $\mathrm{O}$ capitalismo criou as bases para que possamos produzir todos os bens para atender à ampla diversidade de necessidades de cada indivíduo social. Contudo, por ter como objetivo máximo sempre a reprodução do ca- 
pital, é preciso romper com essa lógica, para vislumbrar uma ordem societária que preze pelo humano acima de tudo em sua integridade.

\section{VI}

Feuerbach dissolve a essência religiosa na essência humana. Mas a essência humana não é uma abstração intrínseca ao indivíduo isolado. Em sua realidade, ela é o conjunto das relaçóes sociais.

Feuerbach, que não penetra na crítica dessa essência real, é forçado, por isso:

1. A fazer abstração do curso da história, fixando o sentimento religioso para si mesmo, e a pressupor um indivíduo humano abstrato - isolado.

2. Por isso, a essência só pode ser apreendida como "gênero", como generalidade interna, muda, que une muitos indivíduos de modo natural. (MARX, 2007p. 534).

Esta sexta tese é muito esclarecedora sobre alguns argumentos que intentam reduzir a essência humana a algo fixo e imutável. ${ }^{5}$ Diversos pensadores e ideologias, no passado e no presente, tentam resumir os seres humanos a proprietários privados, mesquinhos, concorrenciais e egoístas por natureza. Os gregos consideravam o escravo como um "instrumentum vocale, um grau acima do gado, que constituía um instrumentum semi vocale, e dois acima do implemento, que era um instrumentum mutum." (ANDERSON, 1991, p. 24). Santo Agostinho, por sua vez, considera a história da humanidade como um processo de "alianças e rupturas entre o homem e seu Criador, iniciando-se com Adão, o primeiro homem, e sua queda, a expulsão do Paraíso, até o juízo final e a redenção, a volta do homem a Deus" (MARCONDES, 2001, p. 112). Hobbes concebe a natureza humana "naturalmente" agressiva e o homem como "lobo do homem". Locke, por exemplo, toma a propriedade privada como um "direito natural" e que é "concedido por Deus" (WOOD, 2001). Rousseau, em seu Contrato social, argumenta a favor do fato de que "o homem nasce bom, a sociedade o corrompe". Contudo, será Marx quem irá avançar sobre os pensadores gregos, medievais e modernos, ao afirmar "o gênero humano como demiurgo de seu próprio destino” (LESSA, 2009, p. 11).

Isso é possível, pois a ontologia instaurada por Marx compreende a essência humana náo como a-histórica e imutável, mas sim como "parte mo-

\footnotetext{
${ }^{5}$ Não é este o espaço próprio para discutir os pormenores acerca da problemática sobre a essência humana. A esse respeito, recomendamos a leitura de Lessa (1999, 2012).
} 
vida e movente da história”. Nessa perspectiva, ele conseguiu provar que é possível superar a propriedade privada, o Estado, as classes sociais, o capital e todo e qualquer tipo de exploraçáo do homem pelo homem. Ninguém nasce escravo, servo, senhor feudal, burguês ou proletário. São as relaçôes sociais que os homens contraem, no processo de produção da riqueza material (isto é, no processo de transformação da natureza para satisfação de suas necessidades), que determinam o local que os indivíduos ocuparáo no processo produtivo. Portanto, Marx comprova e demonstra que "os homens são os demiurgos de seus destinos através da sua descoberta da historicidade da essência: este é o fundamento último da possibilidade ontológica da revoluçáo comunista" (LESSA, 2009, p. 19).

VII

Feuerbach não vê, por isso, que o próprio 'sentimento religioso' é um produto social e que o indivíduo abstrato que ele analisa pertence a uma determinada forma de sociedade. (MARX, 2007 p. 534).

Temos, nesta sétima tese, a demonstração de que Feuerbach, ao não apreender a relação correta entre consciência e realidade social, acaba por isolar a religiáo, sem estabelecer vínculo com a própria objetividade. Assim procedem também alguns educadores, ao incorrerem no equívoco de fragmentar as ideias dominantes de suas vinculaçôes com as classes dominantes e, com isso, defendem - mais por razóes emotivas e sentimentais do que científicas - a mudança de uma ideia apenas por outra ideia que estaria, supostamente, mais correta; por exemplo: muitos são os que criticam a ideologia do agronegócio, táo disseminada em vários contextos, inclusive, em escolas públicas, entretanto, poucos são os que apreendem sua vinculação com o avanço da lógica do capital no campo e a necessidade de superar toda essa ordem societária, para, também, superar a ideologia dominante. Aí reside a necessidade de compreensão da "terrenalidade do pensamento". Marx e Engels já afirmaram, nesse mesmo sentido, que, ao contrário da filosofia alemã que desce do céu para a terra, agora, é da terra que se sobe ao céu, o que significa que é preciso partir não de especulaçóes, representaçóes, sentimentos, sonhos ou utopias de qualquer ordem, mas sim "dos homens realmente ativos e, a partir de seu processo de vida real" para expor o "desenvolvimento dos reflexos ideológicos e dos ecos desse processo de vida” (MARX; ENGELS, 2007, p. 94).

VIII 
Toda vida social é essencialmente prática. Todos os mistérios que conduzem a teoria ao misticismo encontram sua solução racional na prática humana e na compreensão dessa prática. (MARX, 2007, p. 534).

Temos, nesta tese, a defesa da razão, que não "é uma entificação natural, mas que é, como o indivíduo e a própria sociedade, resultado imanente desse conjunto." Trata-se de uma "razão histórica”, já que a "verdade está na efetividade" e a razão "é uma razão do mundo". Assim, tem-se a "defesa da razão histórica e do critério da objetividade como critério de verdade" (CHASIN, 1988, p. 63).

No âmbito da educação, infelizmente, cada vez mais é possível encontrarmos explicaçóes que tendem ao misticismo e ao transcendentalismo, em vários momentos. Desde o ensino de ciências, por exemplo, ao verificarmos explicaçóes de cunho religioso sobre a origem da vida e da humanidade sendo disseminadas, em contraposição a argumentos científicos e racionais; até a compreensão da história da humanidade com um destino já previamente traçado. Este último aspecto é possível em ser constatado nas inúmeras vezes que encontramos educadores ensinando o modo de produção capitalista em sala de aula, sem explicar suas leis profundamente desiguais e incontroláveis. Apresenta-se o capitalismo como a forma de sociabilidade mais coerente com a contemporaneidade e que é possível imputar-lhe reformas, para o melhoramento de alguns quesitos. Junto a tudo isso se ensina massivamente, tanto dentro quanto fora das escolas, que a desigualdade é natural e que, portanto, é impossível uma sociedade para além do capital.

Os efeitos de toda essa lógica têm deixado suas marcas por todos os cantos: um individualismo extremamente exacerbado faz com que cada um viva intensamente o lema do "salve-se quem puder"! O mercado de trabalho, talvez, seja o exemplo clássico por excelência. Não é necessário citar alguma pesquisa empírica para comprovar isso. Aliás, os próprios Marx e Engels, em $A$ ideologia alemã, já nos ensinaram que as ideias dominantes na sociedade serão expressão da classe que exercer dominância no processo de produção da vida em sociedade. Como vivemos ainda sob a regência do capital, na educação (quer em sentido amplo, quer em escolas e universidades, por exemplo), a sociedade capitalista será abordada, na maior parte dos casos, do ponto de vista do seu melhoramento e aperfeiçoamento e não a partir da sua superação. Será transmitido, de modo geral, que se cada um de nós se esforçar arduamente, poderemos nos desenvolver plenamente. Náo por um acaso qualquer, o cri- 
tério de "sucesso", em geral, seja aquele que corresponde ao grau de riqueza (bens e capital) que uma pessoa acumulou em toda a sua vida.

Enfim, a ontologia marxiana baseia-se em argumentos sólidos, historicamente verificáveis, racionais e que explicam a história e as distintas formaçôes sociais, com base na ação real dos próprios homens, sem cair no misticismo da perspectiva que apregoa "estar tudo escrito antes de nós". Por conseguinte:

IX

O máximo a que chega o materialismo contemplativo, isto é, o materialismo que não concebe o sensível como atividade prática, é a contemplação dos indivíduos singulares e da sociedade burguesa. (MARX, 2007p. 535).

Nesta tese há, novamente, uma crítica de Marx ao velho materialismo. Ao desconsiderar a "atividade humana sensível" e a prática enquanto síntese entre objetividade e subjetividade, o máximo a que chega o materialismo antigo é "captar individualidades congregadas em individualidades", ou seja, "o materialismo só consegue dar como existente a individualidade singular, única, que se articula uma com as outras na sociedade civil, burguesa ou econômica" e, assim, "toda a compreensão do velho materialismo, dados os seus limites de concepção das formas de objetividade, faz com que ele só possa perceber indivíduos naturais articulados economicamente na forma do capital" (CHASIN, 1988, p. 63).

$\mathrm{X}$

O ponto de vista do velho materialismo é a sociedade burguesa; o ponto de vista do novo é a sociedade humana, ou a humanidade socializada." (MARX, 2007p. 535).

$\mathrm{Na}$ décima tese da crítica marxiana a Feuerbach, temos uma relevante distinção entre sociedade burguesa e sociedade humana. Lembremos que Marx, em outros escritos, irá distinguir emancipação política de emancipação humana - e esta é uma discussão extremamente relevante e atual, para não vulgarizarmos esses conceitos como se fossem sinônimos. Em primeiro lugar, é preciso ressaltar que Marx não desconsidera o progresso oriundo da constituição da sociedade burguesa. É um fato histórico que o capitalismo desenvolveu as forças produtivas da humanidade de maneira mais intensa e veloz que qualquer outro modo de produção. Igualmente é um fato histórico que a igualdade formal estruturada com base numa desigualdade real no modo de produção capitalista é muito melhor do que a situação dos servos na Idade 
Média ou dos escravos na Idade Moderna. É o que se pode constatar, dentre outras passagens, no seguinte trecho:

\begin{abstract}
A grande indústria criou o mercado mundial, preparado pela descoberta da América. O mercado mundial acelerou enormemente o desenvolvimento do comércio, da navegação, dos meios de comunicação. Este desenvolvimento reagiu por sua vez sobre a expansão da indústria; e à medida que a indústria, o comércio, a navegação, as vias férreas se desenvolviam, crescia a burguesia, multiplicando seus capitais e colocando num segundo plano todas as classes legadas pela Idade Média [...] Cada etapa da evolução percorrida pela burguesia foi acompanhada de um progresso político correspondente. (MARX; ENGELS, 2005, p. 41).
\end{abstract}

Isso é importante para não imputarmos a Marx uma simplificação que ele não operou. Marx reconhece o progresso histórico, político e econômico do capitalismo, frente às "amarras" impostas pelo feudalismo, por exemplo, mas isso não significa que ele concorde com a perspectiva que o encara como a forma de sociabilidade mais desenvolvida possível e que ele seja, portanto, insuperável. Ao contrário, a ontologia marxiana intenta a revolução da totalidade dessa forma societal e náo apenas de uma de suas partes. Tal entendimento, por sua vez, também é fundamental em ser articulado, portanto, à distinção qualitativa entre sociedade burguesa e sociedade humana: a primeira "é a sociedade onde predomina a economia, onde a produção econômica determina o homem, ou seja, é o reino da necessidade”, já a segunda, isto é, a sociedade humana, é "onde predomina o homem, não como único, em seu isolamento natural, mas enquanto feixe de relaçóes sociais", é a sociedade "onde o homem, na sua alma social, determina a produção econômica, ou seja, é o reino da liberdade" (CHASIN, 1988, p. 63).

Em síntese, o processo de constituição da sociedade burguesa é denominado emancipação política e implica "a dissolução da velha sociedade feudal, na qual não havia separação entre sociedade civil e estado e na qual os entes singulares estavam irrevogavelmente subsumidos às ordens sociais ou às corporaçôes de ofício" (TONET, 2005, p. 72). Já a emancipação humana aponta necessariamente para além do capital, para além do Estado e das classes sociais, numa forma societária em que "o destino dos homens estará efetivamente em suas próprias mãos" e, justamente por isso, "a emancipação humana pode e deve ser posta como o fim mais alto da humanidade" (TONET, 2005, p. 155). 
Estes são, em uma brevíssima síntese, os significados de sociedade burguesa, emancipação política e emancipação humana. Assim, do ponto de vista da ontologia marxiana, é impossível, a rigor, ciência, arte, filosofia, educação, geografia etc. "emancipadoras" - em seu conjunto -, estando no âmbito da sociedade capitalista, pois nessa sociabilidade é o capital que tem suas necessidades atendidas e não as reais necessidades humanas. É preciso lembrar que, no sistema do capital, “'expansão’ só pode significar expansão do capital, a que deve se subordinar tudo o mais, e náo o aperfeiçoamento das aspiraçóes humanas e o fornecimento coordenado dos meios para sua realização" (MÉSZÁROS, 2002, p. 131). Dessa forma, a necessidade, do ponto de vista da defesa da humanidade e não do capital, está na convergência das lutas sociais - dentre elas, as lutas educacionais - rumo à emancipação humana e não à tentativa de aperfeiçoamento da sociedade burguesa.

XI

Os filósofos apenas interpretaram o mundo de diferentes maneiras; o que importa é transformá-lo. (MARX, 2007, p. 535).

Por fim, na última tese crítica marxiana, verificamos o aspecto revolucionário e crítico-prático da teoria social instaurada por Marx. De modo algum, o pensador alemão está desprezando o fato de os filósofos terem interpretado o mundo, porém, é necessário também transformá-lo. Assim, "não se trata de deixar de interpretar, mas de interpretar mais amplamente ou diversamente" e, desse modo, "a teoria precisa se ampliar incluindo a reflexão da ou sobre a transformação, ou seja, a subjetividade teórica, racional, crítica, tem que se estender sobre o devir, o transformar e não apenas sobre o em-si das coisas enquanto tais", pois "a nova concepção ontológica demanda isso" (CHASIN, 1988, p. 64). Do ponto de vista dos interesses essenciais dos trabalhadores, há a necessidade de um ensino conscientemente organizado de modo a possibilitar, dentro das condiçôes e circunstâncias concretas, a transmissão e apropriação das objetivaçôes intelectuais científicas, artísticas e filosóficas mais desenvolvidas pela humanidade ao longo da história (SAVIANI, 2011; DUARTE, 2016).

\section{CONSIDERAÇÓES FINAIS}

Neste texto, nosso objetivo foi apresentar as teses críticas de Marx a Feuerbach, com intuito de extrair aspectos elucidativos sobre sua perspectiva 
ontometodológica, os quais contribuam para a discussão educacional. Concordamos com Engels, ao assegurar que as teses são "um esboço genial" e que "estamos diante da certidão de nascimento do pensamento fundamental de Marx", onde se encontram a "instauração ontológica, os lineamentos decisivos da ontologia marxiana do ser social” (CHASIN, 1988, p. 64).

Náo foi nosso objetivo demonstrar como superar o capitalismo rumo à emancipação humana. Isso foge ao espaço e à proposta inicial deste texto. Mostramos, como afirmamos na introdução, que nas Teses contra Feuerbach é possível a reflexão de elementos fundamentais da natureza da teoria social de Marx e como isso é importante também ao debate educacional. Trata-se de uma iniciativa de cunho teórico, que, todavia, não se separa de uma preocupaçáo prática. Como destacamos anteriormente, a teoria, para a ontologia marxiana, deve apreender a essência dos fenômenos estudados, e isso é absolutamente importante para compreender os limites, as possibilidades e os entraves do complexo social da educação, na atual totalidade social dominada pelo sistema do capital.

Marx não inventou uma nova filosofia, uma nova economia, teoria da educação, sociologia etc. Marx instaurou uma nova ontologia, uma ontologia do ser social que está baseada na historicidade do processo de reprodução social efetivado pelos próprios homens, enquanto demiurgos de sua própria história; justamente por isso é radical, ao "agarrar" os fundamentos e as causas daquilo que analisa e, com efeito, aponta para a revolução e não a reforma dessa forma de sociabilidade burguesa. Com as teses contra Feuerbach, temos elementos de suma relevância da ontologia marxiana para o debate educacional, a saber: 1) a síntese entre objetividade e subjetividade, na "atividade prática sensível" dos homens (com a prioridade ontológica da objetividade); 2) a demonstração ontológica da teoria enquanto reprodução ideal do processo real; 3) a necessidade de uma orientação revolucionária ao conhecimento e não apenas a sua transmissão; 4) a transformação da realidade objetiva enquanto condição sine qua non para o fim das alienaçóes; 5) a apreensão dos fenômenos sociais em sua processualidade histórica e 6) o caráter crítico-prático do conhecimento rumo à sociedade humana e não burguesa, ou seja, o conhecimento para entendimento e transformação e não meramente contemplação.

Por fim, vale a pena reafirmar o fato de que a educação e o trabalho, como aqui discutimos, devem ser analisados levando-se em consideração a totalidade inerente ao ser social. Nossas explicaçôes se deram no sentido de introduzir, de modo rápido e superficial, a gama de elucidaçóes que essas ar- 
ticulaçóes engendram. Como Lukács nos ensina: "Sendo a objetividade uma prioridade ontológica primária de todo ente, é nela que reside a constatação de que o ente originário é sempre uma totalidade dinâmica", isto é, "uma unidade de complexidade e processualidade.” (LUKÁCS, 2012a, p. 304).

Contribuir de modo humanamente emancipatório na educação, a favor dos interesses essenciais dos trabalhadores, é propiciar as bases para a transmissão e assimilação dos clássicos das ciências, das artes e da filosofia, como requisito indispensável para a apreensão crítica da sociedade e do processo histórico de autoconstrução humana.

\title{
Agradecimento
}

Pela leitura atenta e observação pertinente, agradecemos à análise de Ivo Tonet.

ROSSI, R. Teses ad Feuerbach and education. Trans/formlação, Marília, v. 42, n. 2, p. 85106, Abr./Jun., 2019.

\begin{abstract}
AвSTRACT: This paper analyses Marx's Theses on Feuerbach in order to extract onto-methodological elements in support of a philosophy of education. We understand, in light of the analyses of Lukács and Mészáros, that Marxian thought differs qualitatively from modern scientific standards because of its introduction of a materialist and dialectical ontology of social being. This means that Marxian social theory has historicity in the ontological approach to social phenomena as its most essential core, and it seeks to understand these phenomena in their genesis and in terms of the social role they play in the process of social reproduction. We treat the revolutionary radicalism of the text under discussion in light of its potential to contribute to the educational debate.
\end{abstract}

KeYwORDS: Marxian ontology. Education. Criticism.

\section{REFERÊNCIAS}

ANDERSON, P. Passagens da antiguidade ao feudalismo. São Paulo: Brasiliense, 1991.

CHASIN, J. Superação do liberalismo. 1988. (Mimeo).

LESSA, S. Notas sobre a historicidade da essência em Lukács. 1999. Disponível em: http:// www.sergiolessa.com/Novaartigos_etallil.html Acesso em: 10 nov. 2015. 
. A atualidade de Marx: a possibilidade da revolução. In: PINHEIRO, M.; FERREIRA, M.; MORENO, R. (Org.) Marx: intérprete da contemporaneidade. Salvador: Quarteto Editora/UNEB, 2009.

. Mundo dos homens: trabalho e ser social. 3. ed. São Paulo: Instituto Lukács, 2012.

LUKÁCS, G. Tecnología y relaciones sociales. In: BUJARIN, N. I. Teoria del materialismo historico. Espanha: Siglo XXI, 1974.

. Para uma ontologia do ser social - I. São Paulo: Boitempo: 2012a.

. Para uma ontologia do ser social - II. São Paulo: Boitempo: 2012b.

MACENO, T. E. O complexo social da educação na reprodução da sociedade: entre a autonomia e a dependência. 2016. 206 f. Tese (Doutorado em Educação) -Universidade Federal de Alagoas, Maceió, 2016.

MARCONDES, D. Iniciação à história da filosofia: dos pré-socráticos a Wittgestein. Rio de Janeiro: Jorge Zahar, 2001.

MARX, K. Crítica da filosofia do direito de Hegel. São Paulo: Boitempo, 2010.

. Grundrisse: manuscritos econômicos de 1857-1858: esboços da crítica da economia política. São Paulo: Boitempo, 2011a.

. O 18 de Brumário de Luis Bonaparte. São Paulo: Boitempo, 2011 b.

MARX, K.; ENGELS, F. Manifesto comunista. São Paulo: Boitempo, 2005.

. A ideologia alemã: crítica da mais recente filosofia alemã em seus representantes

Feuerbach, B. Bauer e Stirner, e do socialismo alemão. São Paulo: Boitempo: 2007.

MÉSZÁROS, I. Para além do capital. São Paulo: Boitempo, 2002.

. A educação para além do Capital. São Paulo: Boitempo, 2005.

PAULO NETTO, J. Introdução ao estudo do método de Marx. São Paulo: Expressão Popular, 2011.

TONET, I. Educação, cidadania e emancipação humana. Ijuí: Unijuí, 2005. 2014.

. Atividades educativas emancipadoras. Rev. Práxis Educativa, v. 9, n. 1, p. 9-23,

WOOD, E. M. A origem do capitalismo. Rio de Janeiro: Jorge Zahar, 2001.

Recebido: 24/07/2016

Aceito: $13 / 08 / 2018$ 